An Empirical Analysis of Franchisee Value-in-Use, Investment Risk and Relational Satisfaction

Associate Professor Debra Grace

Centre for Tourism, Sport and Service Innovation

Department of Marketing

Griffith Business School

Griffith University

Gold Coast, Queensland

Australia

Email: D.Grace@griffith.edu.au

Phone: 61755528027

Dr Scott Weaven

Centre for Tourism, Sport and Service Innovation

Department of Marketing

Griffith Business School

Griffith University

Gold Coast, Queensland

Australia

Email: S.Weaven@griffith.edu.au

Phone: 61755529216

Submitted to: Journal of Retailing

Special Issue - Franchising 


\title{
An Empirical Analysis of Franchisee Value-in-Use, Investment Risk and Relational Satisfaction
}

\begin{abstract}
An exchange perspective of franchising recognizes the important role that both the franchisor and franchisee assume in developing and maintaining sustainable relationships. However, should franchisees not perceive value in the quality of provided products or services, some incentive misalignment between agent and principal is likely (e.g. free riding, non-compliance with system standards), potentially resulting in greater perceptions of financial risk, diminished levels of franchisee satisfaction, reduced unit performance and conflict (Harmon and Griffiths 2008; Kaufmann and Dant 1998). A greater understanding of franchisee perceptions of value is very important if ongoing satisfaction in the franchising relationship is the goal. This paper, therefore, makes a significant contribution to such an understanding by empirically testing the dimensions of value that influence franchisee perceptions of risk and relationship satisfaction. Moreover, we make important comparisons across gender, the results of which provide rich information. In theoretical terms, we advance the literature in the context of value and franchising and, in practical terms, the results, by managing for performance (financial risk and relationship quality), assist franchisors in developing, delivering and managing what is of value to their franchisees. Furthermore, the findings of this study provide a solid platform for future research in this area.
\end{abstract}




\section{Introduction}

Although much of the extant theory on franchising has been developed with a focus on franchisors, there is growing interest in examining the franchise relationship from the franchisee perspective (Grünhagen and Dorsch 2003; Peterson and Dant 1990). Franchise relationships are characterized by a series of relational exchanges, the success of which is dependent upon managing perceived benefits and costs amongst partner entities (Harmon and Griffiths 2008). Accordingly, there is a need for franchisors to better understand the value (Zeithaml 1988) provided to their customers (franchisees) to encourage desired behavioral and performance outcomes, which, in turn, will benefit both parties (Michael 1999). Although perceived value has received considerable attention in explaining customer behavior in traditional retail formats (Huber, Herrmann and Morgan 2001; Sweeney, Soutar and Johnson 1999), research on franchisee’ perceptions of the value of franchisor services is limited (Grünhagen and Dorsch 2003; Harmon and Griffiths 2008; Huang and Phau 2009).

An exchange perspective of franchising recognizes the important role that both the franchisor and franchisee assume in developing and maintaining sustainable relationships. Typically, business format franchisees pay an initial fee and ongoing royalty and fee contributions in return for the right to use the business concept and utilize franchisor-provided services (e.g. management of brand image, provision of locational expertise, development of promotional campaigns) (Combs, Michael and Castrogiovanni 2004). These services, from a servicedominant logic perspective (Merz, He and Vargo 2009, p. 329), entail “the application of competencies (knowledge and skills) for the benefit of another entity (or the entity itself)”, and provide a means for the co-creation of value in franchise relationships. However, should 
franchisees not perceive value in the quality of provided products or services, some incentive misalignment between agent and principal is likely (e.g. free riding, non-compliance with system standards), potentially resulting in greater perceptions of financial risk, diminished levels of franchisee satisfaction, reduced unit performance and conflict (Harmon and Griffiths 2008; Kaufmann and Dant 1998). A greater understanding of franchisee perceptions of value is very important if ongoing satisfaction in the franchising relationship is the goal. This paper, therefore, makes a significant contribution to such an understanding by empirically testing the dimensions of value that influence franchisee perceptions of risk and relationship satisfaction. Moreover, we make important comparisons across gender, the results of which provide rich information. In theoretical terms, we advance the literature in the context of value and franchising and, in practical terms, the results, by managing for performance (financial risk and relationship quality), assist franchisors in developing, delivering and managing what is of value to their franchisees. Furthermore, the findings of this study provide a solid platform for future research in this area.

\section{Conceptual Background}

A central tenet of the exchange view of marketing is value (Bagozzi 1975) which is said to represent a "fundamental basis for all marketing activity" (Holbrook 1994, p. 22). Although recognized as a subjective concept (Gupta and Zeithaml, 2006), value has received considerable scholarly attention in the business-to-consumer (B2C) (Whittaker, Ledden and Kalafatis 2007; Yang and Peterson 2004) and business-to-business (B2B) contexts (Lam, Shankar and Murthy 2004; Palmatier 2008) and has been shown to be a valid predictor of consumer behavior (Grace and O’Cass 2005) and a source of competitive advantage 
(Woodruff 1997). Perceived customer value (PCV) is defined as the "subjective evaluation of the product attributes, performance and the consequences of using that product” (Yu and Fang 2009) and is considered a multi-dimensional theoretical construct dealing with customer perspectives of the quality and price of provider products and services (Chen and Dubinsky 2003; Spiteri and Dion 2004). Given that PCV is contextually dependent (Parasuraman 1997; Zeithaml 1988), empirical examination in the franchising setting (incorporating elements of B2C and B2B marketing exchanges) is warranted and is a necessary first step in understanding what incumbent franchisees actually value and how franchisees may be better engaged in the co-production of value in their networks.

Traditionally, the goods dominant logic views the value driver as "value-in-exchange”. However, we adopt the service dominant perspective of "value-in-use” promoted by Vargo and Lusch (2006) who argue that "there is no value until the offering is used - experience and perception are essential to value determination’ (p. 44). In other words, value is created through the integration of market-facing (i.e. from other firms) and non-market facing (personal/private and public) resources (Vargo, Maglio and Akaka 2008). In the franchising context, this translates to value being created through processes and other elements provided by the franchisor and the franchisee's private (i.e. skills and abilities) resources. This exemplifies the notion of value co-creation which is highly relevant in franchising due to the co-dependency between franchisors and franchisees in relation to value creation and appropriation.

Franchise relationships involve "give and take” cooperation and reciprocity, bounded by contractual stipulations agreed to by both parties (Grünhagen and Dorsch 2003; Harmon and Griffiths 2008). Generally, franchisees are expected to remain as network partners providing 
the benefits they receive (e.g. use of trademark, initial and ongoing training, efficient product procurement) outweigh the costs (e.g. franchise fees, royalties, franchisor opportunism) associated with maintaining the relationship. Grünhagen and Dorsch (2003, p. 368) suggest that the difference between these benefits and costs comprise 'franchisor value", which is defined as the "difference of the overall benefit of being a franchisee and the total cost of acquiring the franchise, including entry fees, royalties and advertising fees”. However, it is suggested here, that such cost/benefit conceptualizations may not fully capture the true essence of value in franchising relationships.

However, considering that franchise relationships involve interplay between human actors (Dant, Weaven and Herington 2008), previous conceptualizations of value in pure B2B contexts (e.g. Harmon and Griffiths 2008; Kulwani and Narayandas 1995, Ulaga and Eggert 2006) may not fully capture relational value in terms of “acquisition value” (i.e. trade-off from entering the franchise relationship) and "transactional value” (i.e. perceptions of psychological pleasure or satisfaction derived from accepting the financial term of the franchise agreement) (Grewal, Monroe and Krishnan 1998) when applied to franchising. Moreover, there is a growing belief that differences between industrial and consumer marketing are artificial (Dant and Brown 2008) and that the nascent Services Dominant (S-D) logic perspective more effectively explains marketing exchange through effectively removing boundaries between producers and consumers (Woodruff and Flint 2006; Vargo and Lusch 2004; Vargo, Maglio and Akaka 2008).

Therefore, from a S-D logic perspective, the central activity of all marketing exchange is based upon customer interaction and sharing knowledge in order for suppliers and customers to co-create value (Ballantyne and Varley 2006). In applying this logic to franchising, we 
consider franchisees to be customers of the franchisor, who co-create value through engaging in a series of product and service-related transactions during the term of their franchising agreements. As beneficiaries of the franchisor's application of bundled services, it is franchisees who ultimately determine value within the franchise relationship (Vargo and Lusch 2004). As franchise units are generally managed by individual entrepreneurs, how they attach meaning to the value of franchisor provider interactions will largely be shaped by their individual traits (e.g. skills, knowledge, and personality) (Michael 1996; Morrison 1997; Weaven, Grace and Manning 2009) and, in this sense, franchising exchange is more likely to resemble traditional B2C consumption situations, incorporating an "amalgam of rational and emotional factors” (MacKay 1999 p. 182). Therefore, both utilitarian and hedonic components (Arnould and Thompson 2005; Holbrook 2006; Sheth, Newman and Gross 1991; Smith and Colgate 2007) are relevant to this study in evaluating how franchisee value-in-use evaluations affect important outcomes, such as the minimization of risk and the enhancement of satisfying relationships between the exchange participants (i.e. franchisor and franchisee).

Thus, in developing our theoretical model, we adapt Sweeney and Soutar's (2001) PERVAL framework which incorporates both physiological and psychological dimensions of value, necessary to “discern the complex nature of perceived value” (Lin, Sher and Shih 2005, p.321). Specifically, the scale was designed to determine what consumption values influence purchase attitude and behavior in consumer goods settings, and consists of four distinct value dimensions (termed, social, emotional, quality (performance) and monetary (price/value for money) and has been shown to allow reliable and valid comparisons of expected benefits and sacrifices in different consumer exchanges (Grace and O’Cass 2005). 
In adopting an exchange perspective to further understand the complexities of franchisee/franchisor exchanges, this article extends the current franchising literature in three key areas: (1) the modeling and empirical examination of the effect of value-in-use evaluations upon relationship outcomes (i.e. risk perceptions and satisfaction) will provide a platform for knowledge enhancement in the domain of franchise value co-creation, (2) the adaption and testing of the PERVAL scale in the context of franchising will inform and extend the operationalization of franchise specific variables, thus providing significant benefits for future studies in this area, and (3) an augmented understanding of gender specific issues in franchising exchanges will address the current literature deficit in this important research area.

\section{Hypotheses Development}

Central to any consumption decision is an individual's assessment of risk (Bozzo 2002; Ulaga and Eggert 2006). Although having no universally agreed definition (Mitchell 1999), perceived risk has been conceptualized as incorporating key components of uncertainty and consequences (Dowling and Staelin 1994), and has been shown to influence consumer decision-making and satisfaction (Aqueveque 2006). Risk dimensions most commonly associated with purchase situations include financial risk, performance risk and social risk (DelVecchio and Smith 2005). However, as franchisees "accept the financial risk of introducing the franchisor's concept to a new and untried market” (Kaufmann and Dant 1998, p. 12), financial or "investment risk" is more applicable in current and future assessments of potential loss. In support of this contention, extant franchising literature confirms that disagreements arising from the allocation of advertising revenues, royalty payments and the size of initial franchise fees constitute the dominant causes of relational conflict and litigation 
in franchising arrangements (Grunhagen and Dorsch, 2003; Porter and Renforth 1998; Tomzack, 1994). Furthermore, franchisees value-in-use assessments approximate a consumer's information search (e.g. scanning information in memory, consideration of external social references or information regarding external choice alternatives) (Brucks 1985; Miniard and Cohen 1983; Payne, Storbacka and Frow 2008) which serve as input to perceived risk assessments (Conchar, Zinkhan, Peters and Olavarrieta 2004). Thus, we position “investment risk" as an outcome of franchisee value-in-use assessments.

Within the marketing literature, customer perceived value has been shown as a reliable predictor of customer search behaviors, purchasing intentions, commitment, satisfaction and loyalty in a variety of retail settings (Brown and Lam 2008; Cronin, Brady and Hult 2000, Beng 1999, Eastlick and Feinberg 1999). A considerable amount of research confirms that product and service quality are positively associated with customer satisfaction (Brady, Knight, Cronin Jr. Tomas, Hult and Keillor 2005; Parasuraman, Zeithaml and Berry 1985). Relationship satisfaction has been defined as the overall positive affective appraisal of one’s exchange partner (Anderson and Narus 1984; Gaski and Nevin 1985; Geyskens, Steenkamp and Kumar 1999; Scheer and Stern 1992). Importantly, customer satisfaction is accepted as a valid predictor of behavioral outcomes including repurchase intentions, positive word-ofmouth and product loyalty in retail settings (Johnson, Gustafsson, Andreassen, Lervik and Cha 2001; Ravald and Gronroos 1996). Additionally, within the franchising context, relational satisfaction has been shown to influence a franchisee’s commitment towards, and intention to remain in the relationship, thus minimising the need for recourse to preventative legislation (Chiou, Hsieh and Yang 2004; Davies, Lassar, Manolis, Prince and Winsor 2009; Geyskens, Steenhamp and Kumae 1999; Hunt and Nevin 1974; Morrison 1997). Schul, Little and Pride (1985, p. 13) define satisfaction as determined by a channel member's "emotional 
attitudes and...feelings about the main characteristics of the organization’s internal environment”. This lends support to the contention that a franchisee's assessment of value-inuse is an antecedent of franchisee satisfaction. Moreover, drawing from the relationship marketing literature, consumer risk perceptions have been shown to be related to trust and cooperation (Doney and Cannon 1997; Morgan and Hunt 1994). On this basis, one would expect that franchisee assessments of risk would influence subsequent satisfaction outcomes, therefore, we hypothesize the following:

H1: Investment risk has a significant negative effect on relationship satisfaction.

Previous value research in franchise settings has focused upon conceptualizing the predictors of franchisee relationship value (Harmon and Griffiths 2008) and examining how franchisee perceptions of value change over time (Grünhagen and Dorsch 2003; Grünhagen, Dorsch and Wollan 2008). To reiterate, in this research we adapt Sweeney and Soutars (2001) fourdimensional PERVAL framework incorporating three benefit components (social, emotional, and quality) and one sacrifice component (monetary). Social value is defined as "the utility derived from the product's ability to enhance self-concept” (Sweeney and Soutar 2001, p. 211). The social dimension is argued to have two underlying factors, i.e. social image and reputation (Sheth, Newman and Gross 1991; Anderson and Weitz 1992). While not mutually exclusive, social image comprises perceptions of the firm's activities and the manner in which it conducts its relationships, and reputation is more about the firm's track record regarding its products and competencies (Callarisa Foil, Alcañiz, Tena and García 2009). How this translates in the context of franchising is quite interesting as the franchisee, upon entering into a franchising agreement, takes on representation of the franchising brand thus creating a strong link between self and brand. Therefore, just as consumers engage in what is labelled as 
“conspicuous consumption” in order to enhance their self-image through the consumption of brands to signal wealth and infer power and status (Veblen 1912), so too, it could be argued that franchisees may purchase a franchise in order to enhance the image they portray to others. This, in turn, would build trust in the relationship and, concomitantly, reduce external search behaviors and resultant perceptions of risk (Mason, 1984; 2005; Moliner, Sánchez, Rodríguez and Callarisa, 2005). On this basis, the social dimension of value is arguably quite applicable in the franchising context. Moreover, we argue that the degree to which the franchisee's self-concept is enhanced (or diminished) through representing the franchise brand will significantly affect (a) the franchisee's assessment of investment risk and (b) the franchisee's overall satisfaction with the franchising relationship. The following hypotheses are therefore posed:

H2a: Social value has a significant negative effect on investment risk.

H2b: Social value has a significant positive effect on relationship satisfaction.

Emotional value, on the other hand, is defined as "the utility derived from the feelings or affective states that a product generates” (Sweeney and Soutar 2001, p. 211), and is a form of consumer knowledge inextricably linked to perceptions of uncertainty and risk (Chaudhuri 1997, p. 82). Anderson and Kumar (2006) argue that emotions play a pivot role in the initiation, development and sustainment of relations. This is so because positive emotions generate feelings of trust and reduce uncertainty in the relationship (Hakannson 1982). This is also argued by Sweeney and Webb (2000) who affirm that feelings of friendship and affinity with the other party stimulate and strengthen relationships, through enhanced perceptions of credibility, honesty and reliability. As developing and sustaining strong relationships in franchising is central to the success and maintenance of strong brands, the 
concept of emotional value should not be overlooked in this context. From the franchisee's perspective, the arousal of positive feelings will provide them with additional "knowledge by acquaintance” (Chaudhuri 1997, p. 82), thereby reducing uncertainty and risk and positively affecting ongoing evaluations of the franchisor's offering. At the same time, franchisees that enjoy/are pleased with owning their franchise will dispel feelings of mistrust and anxiety, thus reinforcing more fluid and lasting relationships (Hennig-Thurau, Gwinner and Gremler 2002). On this basis, we propose the following hypotheses.

H3a: Emotional value has a significant negative effect on investment risk.

H3b: Emotional value has a significant positive effect on relationship satisfaction.

Functional value refers to “the perceived utility acquired from an alternative’s capacity for functional or utilitarian performance” (Sheth, Newman and Gross 1991, p. 160) and this dimension represents a more rational (rather than emotive) dimension to value determination. For the industrial consumer, Sweeney, Soutar and Johnson (1999) promote functional value as being derived from product quality, service quality and price. However, Sweeney and Soutar (2001) argue that functional value has two sub-dimensions, that being, value derived from the perceived performance (quality) of the offering and value for money. Furthermore they argue that these dimensions warrant separate measures. Given this operational separation, functional value (performance/quality) is specifically defined as "the utility derived from the perceived quality and expected performance of the product” (p. 211). We refer to this dimension as quality value.

Franchisee perceptions of the benefits of franchising lie in the proven concept and system (Bürkle and Posselt 2008). Franchisees are attracted to the perceived security that they 
associate with franchisor policies and support that rewards individual effort at the local market level (Grünhagen, DiPietro, Stassen and Frazer, 2008; Michael and Combs 2008), Therefore, the franchisee's ongoing evaluation of how well franchisor initiatives support the management of unit operations (product, service and image consistency, stability of unit operations, franchise unit survival, and ongoing systems support) will determine the degree to which quality value is perceived. Thus, franchisee perceptions of value are predicated upon assessments of how franchisor service delivery facilitates the provision of consistent product and service delivery in franchise outlets and, at the same time, supports the stability and survival of the franchise system as a whole. Should franchisees perceive that franchisors are not strengthening and protecting franchisee interests, they are likely to perceive higher investment risk and be less satisfied with the relationship (Harmon and Griffiths, 2008; Roh and Yoon 2009). Thus, it is expected that the franchisee’s perception of quality value will have a strong influence on their satisfaction with the relationship, and also with their perception of investment risk. This being the case, we hypothesize the following:

H4a: Quality value has a significant negative effect on investment risk.

H4b: Quality value has a significant positive effect on relationship satisfaction.

The second sub-dimension of functional value is price/value for money defined as "the utility derived from the product due to the reduction of its perceived short term and longer term costs’ (Sweeney and Soutar 2001, p. 211). We label this dimension monetary value and, in the franchising context, this represents the value derived from the money paid by the franchisee to the franchisor. As such, this incorporates initial (purchasing price) and ongoing (e.g. royalties, marketing levies etc.) financial contributions. Therefore, this dimension relates specifically to the monetary value associated with the offering (in this case, the 
franchising arrangement). Previous research confirms that increasing royalty contributions are a major source of relational conflict and franchisee exit (Michael and Combs 2008), as it makes it more difficult for franchisees to extract profit from their investments (Scott Jr. 1995). Thus, it is expected that a franchisee's evaluation of investment risk will be significantly influenced by the perceived value for money in their current franchising agreement. For example, more satisfied franchisees are with their financial arrangements, the less likely they will be to perceive high investment risk associated with franchising. Similarly, the more franchisees perceive positive monetary outcomes then the more likely they are to positively evaluate the franchising relationship. Therefore, we pose the following:

H5a: Monetary value has a significant negative effect on investment risk.

H5b: Monetary value has a significant positive effect on relationship satisfaction.

The preceding discussion outlines the hypotheses proposed in this study which depict relationships between four dimensions of value (i.e. social, emotional, quality and monetary value) with investment risk and relationship satisfaction. These relationships are graphically illustrated in the conceptual model shown in Figure 1 and hypotheses are shown accordingly.

\section{--- Insert Figure 1}

The modeling of the hypotheses in Figure 1 positions investment risk as a quasi-mediating variable. We argue for investment risk to be a quasi-mediator in the relationships between the independent variables (social value, emotional value, quality value and monetary value) and the dependent variable (relationship satisfaction), as opposed to fully mediating this 
relationship, on the following basis. Here we make a distinction between the quasi-mediator variable (investment risk) and the remaining variables in the model.

The franchisee's perception of value and satisfaction is manifested predominantly, within the franchise exchange. In other words, it is the franchisee's experience with the franchisor that will determine the degree (and manner) to which they extract value, and are subsequently satisfied with the relationship. Thus, their evaluations are fully embedded within the franchising exchange and, as a result, direct relationships have been hypothesized. The perception of investment risk, however, is partially embedded in their experiences of franchising and partially embedded within the individual. For example, it has been well established within the management and decision-making literature that risk propensity is a individual trait (i.e. individuals have a tendency to be either risk-adverse or risk-seekers) that has a significant influence on emotional and behavioral outcomes (Das and Teng 2001; Keil et al 2000; MacCrimmon and Wehrung 1986, Sitkin and Pablo 1992). As such, in the context of franchising, a risk adverse individual may still perceive high investment risk regardless of their positive experiences, whereas risk-seekers may be less reactive to negative experiences. The same argument cannot be made for value and relationship satisfaction as, inherently, all individuals tend to seek out value and satisfaction, rather than being adverse to them. On this basis, it is expected that the variance in investment risk will be partially accounted for by individual differences and partially accounted for by the value dimensions, thus we hypothesize that investment will be a quasi-mediator (not a full mediator) in the relationship between the value dimensions and relationship satisfaction. 
H6: Investment risk will act as a quasi-mediator in the relationship between the independent variables (social value, emotional value, quality value and monetary value) and the dependent variable (relationship satisfaction).

\section{Gender Differences}

While the validation of the conceptual model provides a basis for us to understand value creation in the franchising relationship, it is the breakdown of this model across gender that may exhibit richness of information. Given that franchisees are not a homogeneous group of individuals, it is important to analyze how well-defined groups (such as males and females) behave within the franchising relationship. Importantly, such differences need to be established as some segments (particularly service-dominated segments) are predominately occupied by male franchisees (e.g. vehicle maintenance, garden maintenance etc.), and others are largely dominated by females (e.g. hair dressing, domestic cleaning etc.) (Dant, Brush and Iniesta 1996).

Extant small business literature points to fundamental differences in the priorities and expectancies females and males attach to business ownership (Sorenson, Folker and Brigham 2008). Conventional wisdom posits that females are more oriented toward building collaborative and cooperative relationships (McKay 2001) than males, which may account for differences in the emotional value they derive from franchise ownership and the way they perceive the value of franchisor-provided services. Furthermore, females often find difficulty in obtaining finance, and by placing high value on the security of their family (Olsen and Currie 1992) may have markedly different perceptions of the franchise’s "value for money”. Moreover, males are often depicted as valuing status-based career satisfiers more than females (DeMartino and Barbato, 2003), which suggests that male franchisees may place greater 
emphasis on the "social value" derived through franchise ownership. Therefore, resultant perceptions of investment risk and levels of satisfaction in the franchise relationship are likely to differ between males and females. Previous research by Jambulingam and Nevin (1999) lends partial support to this contention finding that, generally, females were less satisfied with the performance of franchising business models, than males. These are key variables in our model, and as such, we expect that value-in-use assessments of the franchising relationship will differ between male and female franchisees. Given the previous discussion it is hypothesized that:

H7a: The effect of emotional value and monetary value on investment risk will be stronger for female franchisees.

H7b: The effect of emotional value and monetary value on relationship satisfaction will be stronger for female franchisees.

H7c: The effect of social value and quality value on investment risk will be stronger for male franchisees.

H7d: The effect of social value and quality value on relationship satisfaction will be stronger for male franchisees.

\section{Empirical Research}

Data for this study was collected from Australian franchisees via an on-line survey. The sampling frame used was a database of 10,000 franchisee contacts. This database was developed by gathering the websites of Australian franchise systems from the Yellow Pages telephone directory. The contact emails of franchisees of these systems were then sought 
from their respective websites, resulting in a database consisting of 10,000 franchisee contacts across Australia. From this sampling frame, 3,000 e-mail addresses were randomly generated and respondents were invited, by e-mail, to participate in the survey. As an incentive, participating respondents were entered into a prize draw for an iPhone. This resulted in 263 surveys being completed, representing a 9\% response rate. Given the forced response nature of the online survey, there were no missing data. As non-response bias was a concern, we contacted 100 non-responders to elicit interest in completing the survey. The collection of a further 59 surveys for non-response testing resulted from these contacts. A comparison of mean scores between the original sample and the non-response sample, over the six key constructs of this study, revealed no significant differences between samples. Only the original sample was used for analysis.

\section{Survey Measurement}

A review of previous studies in relation to value, risk and satisfaction identified a number of pre-existing scales that had been well validated in the literature. While the scales identified were appropriate for the measurement of the constructs of this study, they had not been previously used in the context of franchising. For example, the four dimensions of value (social, emotional, quality and money) were measured via Sweeney and Soutar's (2001) PERVAL scale and the measurement of investment risk was adapted from Aqueveque (2006), both predominantly used in consumer behavior research. In terms of PERVAL, the previous discussion has established why the four dimensions of PERVAL (social value, emotional value, quality value and monetary value) can be appropriately applied in the context of franchising. While the PERVAL items were adapted to measure value-in use (and, as a result, were specifically adapted in the context of the franchisee’s present franchising situation), the 
items pertaining to investment risk were adapted to measure the franchisee’s risk perceptions of franchising in general. Given that the franchising format is "sold" on the basis of being a less risky business format than others (Kaufmann, 1999; Peterson and Dant, 1990; Tikoo, 2002), it is expected that franchisees, upon entering into their franchising agreement, may do so with a lower level of perceived investment risk. Thus, this forms the baseline upon which their expectations of risk is established and upon which future risk evaluations will be compared. Consistent with this baseline comparative evaluation, investment risk was measured in the context of franchising in general. Finally, the relationship satisfaction scale was adapted from Li and Dant’s (1997) perceived performance measure previously used in the context of channel relationships. The perceived performance scale was deemed a suitable measure of satisfaction as it captures channel members' "overall perceptions about channel productivity and worthiness and [taps into] their satisfaction with channel relationships” (p. 208). The adapted items appear in Table 1, along with the analysis of psychometric properties (discussed later). All items were measured on a 7-point Likert scale ranging from "Strongly Disagree” (1) to "Strongly Agree” (7).

\section{Sample Description}

The gender split of the franchisee sample was $70 \%$ male, $30 \%$ female and the mean age was 43 years. On average, respondents had been self-employed for 10 years and $67 \%$ were singleunit owners, while the remaining 33\% were multi-unit franchise owners. In terms of education, 32\% had university degrees, 33\% had technical qualifications and 35\% were educated to secondary school level. Fifty-one percent of the sample had prior business (nonsalaried) experience before purchasing their current franchise. Respondents came from a diverse range of industries that can be broadly summarized as retail trade, administrative and 
support services, rental and real estate services, financial and insurance services, education and training and other miscellaneous services.

\section{Analysis and Results}

Preliminary analysis of the data included examination of measures of central tendencies and dispersion and visual inspection of the data via histograms, skew and kurtosis. The results indicated that the data was normally distributed, thus meeting this requirement for structural equation modeling (Byrne, 2001). Using AMOS 17.0, the data was then analyzed via a twostep process recommended by Anderson and Gerbing (1988) by, firstly, examining the measurement model and then the structural paths associated with the hypotheses of this study. In addition, tests for mediation were conducted to test for rival models and multi-group analysis between the male and female samples was conducted to address H7.

\section{Measurement Model}

The 23 items pertaining to the six constructs of the proposed model were examined via confirmatory factor analysis (CFA), with the initial analysis indicating only a moderate fit: $X^{2}$ $=747.32(d f=215, p<.05)$, goodness of fit index (GFI) of .80, comparative fit index (CFI) of .93, Tucker-Lewis-index (TLI) of .92 and root mean square of approximation (RMSEA) of .09. Individual item reliabilities, represented by the squared multiple correlations (SMCs), were examined in order to determine the adequacy of the reflective indicators as measures of 
their respective constructs (see Bollen and Lennox 1991). In addition, cross-loadings were examined via modification indices and standardized residuals (Leite et al. 2008) and this indicated that SOCVAL1, QUALVAL4 and MONVAL4 were significantly cross-loading onto other latent constructs. These items were excluded from further analysis. The remaining items were subjected to CFA again and this resulted in an acceptable fit of the measurement model: $X^{2}=318.74(d f=155, p<.05)$, GFI .90, CFI .97, TLI .97 and RMSEA .06. Table 1 provides a summary of the standardized loadings (SL), composite reliabilities (CR) and average variance extracted (AVE) for the respective items and constructs.

\section{--- Insert Table 1}

Measure Validation

Convergent Validity: Convergent validity was evaluated in three ways i.e., by evaluating the strength and significance of the factor loadings, by examining the composite reliabilities and by inspecting the average variance extracted (AVE) for each construct (similar to Baldauf et al. 2009). All standardized loadings are significant, positive and strong ( $\mathrm{t}>$.20) (Gerbing and Anderson 1988), with standardized loadings ranging from .70 to .99, (lowest critical ratio being 8.039), indicating a high degree of convergence (Bagozzi and Heatherton 1994). The composite reliabilities are all well in excess of the .70 cut-off value suggested by Bagozzi and Yi (1988), and all AVEs exceed .50, as recommended by Fornell and Larcker (1981).

Discriminant Validity: The data was further assessed for discriminant validity. The $X^{2}$ difference test was undertaken (Bagozzi et al. 1991), which involved 15 comparisons of the constrained and unconstrained measurement models of all construct pairs. For example, the 
phi value for each pair of the six latent variables in the unconstrained measurement models were constrained to 1 , one at a time, and then the $X^{2}$ difference was calculated for each pair of unconstrained and constrained models (similar to Li and Dant 1997). The results of these comparisons appear in Table 2. Of the 15 comparisons conducted, four comparisons did not pass the $X^{2}$ difference test (i.e. $\mathrm{p}>.01$ ), thus indicating that the constructs did not discriminate. All of the four failed comparisons involved the SOCVAL construct, clearly indicating that this measure was problematic. On this basis, SOCVAL was eliminated from all further analyses. Given the deletion of this construct, the measurement model was run again and an acceptable fit was achieved: $X^{2}=204.16(d f=108, p<.05)$, GFI .92, CFI .98, TLI .98 and RMSEA .05.

\section{--- Insert Table 2}

Common Method Bias: As single sources of information can introduce spurious relationships among the variables, and as this study collected data via the same method (self-report survey), the need to test for common method bias was warranted. In the behavioral sciences, there have been a number of published techniques which assist with the assessment of common method bias (e.g. partial correlation procedures, Harman’s single-factor test, multiple method factors test etc.), however, no test is without its disadvantages (Podsakoff et al. 2003). To test for common method bias we selected two distinctly different tests i.e., marker variable technique (Lindell and Whitney 2001) and the chi-square difference test (e.g., Baldauf et al. 2009). Firstly, we selected "I always know whether or not I am happy” taken from an Emotional Intelligence Scale (Wong and Law 2002) as the marker variable as there was no theoretical basis upon which to suspect this variable would be related to our independent and dependent variables. After controlling for the marker variable, there was no difference in the 
statistical significance of the construct correlations, thus indicating that common method bias was not problematic in the data. Secondly, we loaded the 17 items onto a common factor and conducted CFA. The results were then compared with the results of the CFA of the measurement model, which comprised of 5 latent variables. The chi-square different test was applied and, given the deterioration in $X^{2}$ by $1745.16(\mathrm{p}<.01)$, the measurement model was shown to be significantly superior in representing the data, as opposed to the common-factor model. As such, the results of two common-method bias assessments indicate that common method bias was not evident in the data.

\section{Hypotheses Testing}

The overall structural model was tested using AMOS 17.0. The model fit is good with $X^{2}=$ $182.31(\mathrm{df}=108, \mathrm{p}<.05)$, GFI .93, CFI .99, TLI .98 and RMSEA .05. Further examination of the structural path coefficients indicate that of the seven hypothesized paths tested, only one path was not significant i.e,. QUALVAL $\rightarrow$ SATIS. Thus, H1, H3 a \& b, H4a, H5 a \& b are supported, while H4b is not (please bear in mind, H2a \& b were not tested due to unsatisfactory discriminant validity of SOCVAL). Dependent variables exhibited high $\mathrm{R}^{2}$ values, i.e., SATIS (.79) and RISK (.65), thus representing an average variance accounted (AVA) for in the model of .72. Results of hypotheses testing appear in Table 3, including beta weights and critical ratios of the hypothesized paths, R-squared of the dependent variables, AVA and model fit statistics. In addition, the results are graphically depicted in Figure 2.

\section{--- Insert Table 3 \& Figure 2}

Testing for Mediation 
Mediation testing was undertaken along the guidelines of James, Mulaik and Brett (2006) and, more specifically, used in the context of marketing by Luo and Bhattacharya (2006) and Bauldauf et al. (2009). The subsequent tests were used to determine if RISK mediated the relationship between the independent variables (i.e. EMOVAL, QUALVAL and MONVAL) and the dependent variable (SATIS). Prior to conducting such a test, it is important to, firstly, determine if all the independent variables (EMOVAL, QUALVAL and MONVAL) directly impact the mediator (RISK). Referring to Model 1 (Table 4), it is clear that this requirement has been satisfied. Secondly, the mediator (RISK) must directly impact the dependent variable (SATIS) and this is also evident in Model 1 (Table 4). The third condition is that the independent variables (EMOVAL, QUALVAL and MONVAL) must significantly impact the dependent variable (SATIS). The condition was satisfied in 2 of the 3 cases, with QUALVAL $\rightarrow$ SATIS being the only non-significant path shown in Model 2.

The final test for full mediation involves testing whether the mediation model i.e., Model 1 (with paths from EMOVAL. QUALVAL and MONVAL going through RISK to SATIS, but not directly to SATIS) provides a better fit than the no-mediation model where the path between RISK and SATIS is not included, thus eliminating any indirect effects (Model 3). A $X^{2}$ difference test was conducted to show which model provided the best fit and, in this case, the no-mediation model (Model 3) was significantly better than the mediation model $\left(\Delta X^{2}=\right.$ 32.27, $\Delta \mathrm{df}=2, \mathrm{p}<.001$ ), thus rejecting full mediation. In order to test for quasi-mediation, we compared the mediation model (Model 1) with the full model where both direct and indirect paths were specified (Model 4). In comparing Model 1 (full mediation) to Model 4 (quasimediation), the results indicate that Model 4 is significantly better than Model $1\left(\Delta X^{2}=\right.$ 49.17, $\Delta \mathrm{df}=3, \mathrm{p}<.001$ ), indicating evidence of quasi-mediation in support of H6. 


\section{--- Insert Table 4}

Testing for Gender Differences

To address H7a and H7b, the sample was split based on gender and individual SEMs were performed on Model A (males, $\mathrm{n}=183$ ) and Model B (females, $\mathrm{n}=80$ ). The results indicate a good fit for Model A ( $X^{2}$ of 156.12 on $108 d f, p<.01$; GFI = .91; TLI = .97; CFI = .98; RMSEA = .05). Model B exhibited a $X^{2}$ of 166.08 on $108 d f, p<.01$; GFI = .78; TLI = .95; CFI $=.97 ;$ RMSEA $=.09$. All statistics for Model B were at the appropriate levels except the GFI, which was low. It is suggested that this was the result of having large degrees of freedom, when compared to sample size. In order to determine if Model A and Model B were significantly different, a chi-square difference test was undertaken. The results indicate $\Delta X^{2}$ $=7.96, p<.01$, thus supporting further exploration of parameter differences (refer to Table 5).

\section{--- Insert Table 5}

Firstly, the significance of the corresponding paths of Model A and Model B were examined and the significant paths are shown in Figure 3. Differences in significant paths were revealed for the paths EMOVAL $\rightarrow$ RISK and RISK $\rightarrow$ SATIS, which were both significant for Model A, but not significant for Model B. Secondly, t-tests were performed on the corresponding path beta weights of the models to determine if there were differences in the strengths of the paths. The results indicted that two paths were stronger for Model B (Females) i.e. MONVAL $\rightarrow$ SATIS (Model 1, $\beta=.17$, Model 2, $\beta=.42, t=-13.85, p<.01$ ) and MONVAL $\rightarrow$ RISK (Model 1, $\beta=-.22$, Model 2, $\beta=-.42, t=21.96, p<.01$ ). R-squared values for the dependent variables, RISK and SATIS, were also compared across the models, with minimal differences found (i.e. Model 1: RISK $=.70$, SATIS $=.80$; Model 2: RISK $=$ 
.64 , SATIS $=.81)$, although the average variance accounted for in Model A $($ AVA $=.75)$ was slightly greater than Model B (AVA = .72).

Therefore, H7a is partially supported in regards to the relationship between MONVAL and RISK which was significantly stronger for females (however, the relationship between EMOVAL and RISK was not stronger for females, in fact, males were stronger in this relationship). In the context of H7b, the relationship between MONVAL and SATIS is significantly stronger for females (but the relationship between EMOVAL and SATIS was not stronger for females, but the same as the male model), thus this hypothesis is also partially supported. With regards to H7c, this hypothesis was not supported as the relationship between QUALVAL and RISK was not significantly different between males and females. Finally, H7c was also not supported as the relationship between QUALVAL and SATIS was not significant for either model.

--- Insert Figure 3

\section{Discussion and Conclusion}

Empirical testing of the proposed model clearly validates that franchisees assess value in a multi-dimensional way, as do customers in a B2C setting. For example, the franchisee’s perception of the perceived performance that is derived from the franchisor/franchisee relationship comes in the form of perceived quality and positive feelings and perceived value for money. It is these value perceptions that significantly influence the franchisee's assessment of investment risk and relationship satisfaction. This finding is particularly important given that franchisee satisfaction has significant benefits for both parties 
(franchisee/franchisor) in terms of loyalty, trust and commitment (Harmon and Griffiths 2008).

However, when examining the relationship between value assessments and perceptions of investment risk, in contrast to value assessments and relationship satisfaction, a slightly different picture emerges. For example, quality perceptions, positive feelings and monetary value all significantly reduce one’s assessment of investment risk associated with franchising in general. However, it is only emotional value and monetary value that affects relationship satisfaction associated with their current franchising exchange. This is an interesting finding, and one in which confirms Sweeney and Soutar's (2001) argument that functional value is comprised of two distinct dimensions, that being performance value and monetary value, and further provides support for their separate operationalization. The results here clearly indicate that each dimension (i.e. quality value and monetary value) performs in distinctly different ways.

In terms of reducing investment risk, franchisees expect positive emotional experiences, the performance (or quality of performance) of their particular unit to be in-line with the quality of the system they have "bought into", and a perception that they have indeed received what they paid for (monetary value). If all of these conditions are met, their perceptions of the investment risk associated with operating a franchised business will be minimized and, subsequently reinforce future investment in franchising. The lowering of investment risk will, in turn, enhance the franchisee's positive evaluation of their current satisfaction with the relationship. 
However, in direct association with relationship satisfaction, is emotional value and monetary value, which indicates that value-in-use assessments are predominantly comprised of emotional (EMOVAL) and rational (MONVAL) components. However, it is interesting to note, in the results, that emotional value was much stronger than monetary value. This indicates that franchisees place significant importance on (and derive significant value from) the "soft" components of the franchising exchange. This confirms the views of others (e.g. Chaudhuri 1997; Hennig-Thurau, Gwinner and Gremler 2002) that positive emotional exchanges between franchisors and franchisees enhance trust and commitment, and facilitate positive outcomes in future exchanges (Harmon and Griffiths 2008).

The results based on gender comparisons, clearly indicate that females place significant importance on gaining monetary value and this significantly enhances their relationship satisfaction and diminishes their perception of risk associated with franchising. This finding is contrary to the argument that females apportion more value to relationship building (Gilligan 1982; Brush and Hisrich, 1991; McKay, 2001) than males, but is consistent with Weaven, Isaac and Herington (2008) who posit that females place significant importance on financial remuneration and business growth. The importance of value for money among female franchisees may well stem from reduced opportunities to source finance and the sacrifices they make in terms of family-life balance (Olsen and Currie 1992). In other words, if finance is difficult to attain, and should females have to make significant family sacrifices, then the only way females can justify such sacrifices/difficulties is by reaping substantial financial remuneration to enhance their financial and family status. This explains why females may evaluate both relationship satisfaction and investment risk predominantly on their perceptions of monetary value.

\section{Limitations}


One limitation of this study arises from the use of a survey method to collect data. This is so because all survey research involves measurement error which will be influenced by the degree to which the respondent has the ability to accurately report their level of agreement or feelings with regards to the survey statement. However, data analysis of the measurement model suggests that measurement error was not problematic and this is reflected in the reliability analysis and other validity checks. Furthermore, there is always concern as to the representativeness of the data when response rates are low (9\% in this study), however, extra

effort was exerted to gather data from non-respondents and tests on the data revealed that nonresponse bias was not evident. Finally, as data were collected from Australia the generalizability of the results may be limited beyond this region. However, given the similarities between the Australian franchising landscape and that of the UK and the USA, the results of this study could well be applied in a much broader context.

While the concept of social value cannot be discussed here, given that the measures were found to be inappropriate for analysis, it is important to acknowledge that this may have occurred because the relevant items, as adapted in the franchising setting, were not applicable to this context. Rather than measuring items that capture self-concept directly, it might be more appropriate (in small business settings) to measure the likes of, for example, prestige that indirectly relates to the same concept.

\section{Implications and Future Research}

In theoretical terms, this research has expanded our understanding of value derivation, perceived risk and satisfaction in the franchise exchange. In this study, we adopt a multidimensional approach to exploring value-in-use, not yet attempted in the franchising context. 
The findings clearly indicate that such a multi-dimensional approach is valid within this context, however, individual differences among franchisees have a significant impact on how these dimensions perform in the context of the conceptual model. This indicates that, in the domain of franchising, it is important that individual differences are not overlooked when sweeping generalizations are made. Therefore, a more in-depth exploration of the impact of individual variables (over and above demographic variables), such as relationship orientation, personality and decision-making styles on value derivation, in the future, would enhance our understanding of individual behavior in this context. Moreover, future research should consider the influence of an individual's “gender identity” (Eddleston and Powell 2008) in explaining sex differences in value-in-use assessments in franchising.

Secondly, as this study clearly shows that franchisee perceived value impacts, in various ways, on franchisee satisfaction and risk perceptions, an interesting extension to this work would be the examination of value creation and value appropriation within franchising systems including comparisons over (1) different industries, (2) different systems (i.e. new versus mature systems) (3) different governance structures (i.e. master franchising, area development, sequential expansion) and, (4) different ownership structures. This can be accomplished using the framework of "value co-creation among service systems" conceptualized by Vargo, Maglio and Akuka (2008). This framework, in its current form, depicts value-in-use from the firm's perspective and from the customer's perspective, arguing that both are valid service systems. Even more so, this applies to franchising in which the franchisor and franchisee are two separate service entities that must interact in order for value to be produced for both parties. In the franchising context, this model could be extended even further to examine the co-creation of value between franchisors, franchisees and customers. In doing so, significant advancement of theory would result. Finally, the gathering of 
longitudinal data would also significantly enhance our knowledge in this area as this would enable tracking of the dynamics of value creation in franchising over time.

In practical terms, franchisors need to closely consider their product offerings to ascertain what aspects contribute to the value derived by franchisees. In using the three dimensions of value explored here, franchisors should determine what dimensions are particularly pertinent in the context of their franchise. For example, franchisors wanting to develop and sustain strong relationships with franchisees need to appeal to the emotions of their franchisees in order to develop trust and loyalty. While this could be argued to be just a case of common sense, franchisors, in their efforts to maintain a quality product offering, may well overlook important intrinsic (franchisee) factors as that discussed. This could be the result of adopting the more traditional and narrow mindset which is restricted to quality/price perspectives.

Secondly, the findings here suggest that real differences in value derivation do exist between male and female franchisees. This is an important finding for franchisors who may seek to attract and maintain relationships with one particular gender over the other. For example, should female recruitment be the goal, then clearly communicating the monetary benefits associated with the franchise and/or offering “guarantees” in the attempt to reduce the perceived investment risk, would constitute a worthwhile strategy. Arguably, having knowledge of individual group behavior is a valuable tool that provides an efficient means to strategic targeting. Thus, as previously discussed, further segmentation of value creation and appropriation, in the franchising context, should dominate future research. 


\section{Acknowledgements}

The authors would like to thank the editors and the three anonymous JR reviewers for their invaluable help in revising the manuscript. This research was supported by a grant from the Centre for Tourism, Sport and Service Innovation, Griffith University. 


\section{References}

Anderson, James C. and David W. Gerbing (1988), "Structural Equation Modeling in Practice: A Review and Recommended Two-Step Approach,” Psychological Bulletin, 103 (3), 411-423.

Anderson, James C. and James A. Narus (1984), “A Model of the Distributor’s Perspective of Distributor-Manufacturer Working Relationships, Journal of Marketing, 48 (4), 62-74.

Anderson, Erin and Barton Weitz (1992), "The Use of Pledges to Build and Sustain Commitment in Distribution Channels,' Journal of Marketing Research, February, 1854.

Anderson, Poul H. and Rajesh Kumar (2006), "Emotions, Trust, and Relationships in Business Relationships: A Conceptual Model for Buyer-Seller Dyads,” Industrial Marketing Management, 35 (4), 522-535.

Aqueveque, Claudio (2006), "Extrinsic Cues and Perceived Risk: The Influence of Consumption Situation,” Journal of Consumer Marketing, 23 (5), 237-247.

Arnould, Eric J. and Craig J.Thompson (2005), “Consumer Culture Theory (CCT): Twenty Years of Research,” Journal of Consumer Research, 31 (March), 868-882.

Bagozzi, Richard P. (1975), "Marketing as Exchange,” Journal of Marketing, 39 (October), 32-39.

Bagozzi, Richard P. and Todd. F. Heatherton (1994), “A General Approach to Representing Multifaceted Personality Constructs: Application to State Self-Esteem,” Structural Equation Modeling, 1 (January), 35-67.

Bagozzi, Richard P. and Youjae Yi (1988), "On the Evaluation of Structural Equation Models,” Journal of the Academy of Marketing Science, 16 (Spring), 74-94.

Bagozzi, Richard P., Youjae Yi and Lynn W. Phillips (1991), “Assessing Construct Validity in Organizational Research,” Administrative Science Quarterly, 36 (September), 421458.

Ballantyne, David and Richard J. Varley (2006), “Creating Value-in-Use through Marketing Interaction: The Exchange Logic of Relating, Communicating and Knowing,” Marketing Theory, 6 (3), 335-348.

Bauldauf, Artur, Karen S. Cravens, Adamantios Diamantopoulos and Katharina Petra Zeugner-Roth (2009), "The Impact of Product-Country Image and Marketing Efforts on Retailer-Perceived Brand Equity: An Empirical Analysis,” Journal of Retailing, 85 (December).

Beng, Soo Ong (1999), "Determinants of Purchase Intentions and Stock-Piling Tendency of Bonus Packs,” American Business Review, 17 (1), 57-64.

Bollen, Kenneth .A. and Richard Lennox (1991), "Conventional Wisdom on Measurement: A Structural Equation Perspective,” Psychological Bulletin, 110, 305-314.

Bozzo, Cecile (2002), “Understanding Inertia in an Industrial Context,” Journal of Customer Behavior, 1 (3), 335-355.

Brady, Michael K, Gary A. Knight, J. Joseph Cronin Jr., G. Tomas, M. Hult and Bruce D. Keillor (2005), "Removing the Contextual Lens: A Multinational, Multi-setting Comparison of Service Evaluation Models,” Journal of Retailing, 81 (3), 215-230.

Brown, Steven P. and Son K. Lam (2008), “A Meta-analysis of Relationships Linking Employee Satisfaction to Customer Responses,” Journal of Retailing, 84 (3), 243-255.

Brucks, Merrie (1985), “The Effects of Product Class Knowledge on Information Search Behavior,” Journal of Consumer Research, 12 (1), 1-16.

Brush, Candida G. and Robert D. Hisrich (1991), "Antecedent Influences on Women-Owned Businesses,” Journal of Managerial Psychology, 6 (2), 9-16. 
Bürkle, Thomas and Thorsten Posselt (2008), "Franchising as a Plural System: A Risk-Based Explanation,” Journal of Retailing, 84 (1), 39-47.

Byrne, Barbara M. (2001), Structural Equation Modeling with AMOS, Basic Concepts, Applications, and Programming, Mahwah, NJ: Lawrence.

Callarisa Foil, Luis J,,Enrique Bigne Alcañiz, Miguel A. MolinerTena and Javier Sanchez García (2009), "Customer Loyalty in Clusters: Perceived Value and Satisfaction as Antecedents,” Journal of Business-to-Business Marketing, 16, 276-316.

Chaudhuri, Arjun (1997), "Consumption Emotion and Perceived Risk: A Macro-Analytic Approach,” Journal of Business Research, 39 (2), 81-92.

Chen, Zhan and Alan J. Dubinsky (2003), "A Conceptual Model of Perceived Customer Value in E-Commerce: A Preliminary Investigation,” Psychology \& Marketing, 20 (4), 323-347.

Chiou, Jyh-Shen, Chia-Hung Hsieh and Ching-Hsieh Yang (2004), “The Effect of Franchisor's Communication, Service Assistance, and Competitive Advantage on Franchisee's Intention to Remain in the Franchise System,” Journal of Small Business Management, 42 (1), 19-36

Combes, James G., Steven C. Michael and Gary J. Castrogiovanni (2004), "Franchising: A Review and Avenues to Greater Theoretical Diversity,” Journal of Management, 30 (6), 907-931.

Conchar, Margy P., George M. Zinkhan, Cara Peters and Sergio Olavarrieta (2004), “An Integrated Framework for the Conceptualization of Consumers' Perceived Risk Processing,” Journal of the Academy of Marketing Science, 32 (4), 418-436.

Cronin, Joseph Jr, Michael K.Brady and G. Tomas M. Hult (2000), “Assessing the Effect of Quality, Value, and Customer Satisfaction of Consumer Behavioral Intentions in Service Environments,” Journal of Retailing, 76 (2), 193-218.

Dant, Rajiv P and James R. Brown (2008), "Bridging the B2C and B2B Research Divide: The Domain of Retailing Literature,” Journal of Retailing, 84 (4), 371-397.

Dant, Rajiv, P., Candida Brush and Francisco P. Iniesta (1996), "Participation Patterns of Women in Franchising,” Journal of Small Business Management, 34 (2), 14-28.

Dant, Rajiv P. and Alden Peterson (1990), "Perceived Advantages of the Franchise Option from the Franchisee Perspective Empirical Insights from a Service Franchise," Journal of Small Business Management, 28 (3), 46-61.

Dant, Rajiv P., Scott K. Weaven and Carmel Herington (2008), “Franchisee Personality Traits, Gender and Multi-Unit Structure as Predictors of Franchisee-Franchisor Relationship Strength," Proceedings of $22^{\text {nd }}$ Annual International Society of Franchising Conference, Saint Marlo, Brittany, France.

Das, T.K. and Binsheng Teng (2001), "Strategic Risk Behavior and Its Temporalities: Between Risk Propensity and Decision Context. Journal of Management Studies, 38 (4), 515-534.

Davies, Mark A. P., Walfried Lassar, Chris Manolis, Melvin Prince, Robert D. Winsor, (2009), “A Model of Trust and Compliance in Franchise Relationships, Journal of Business Venturing, (forthcoming).

DelVecchio, Devon and Daniel C. Smith (2005), "Brand Extension Price-Premiums: The Effects of Perceived Fit and Extension Product Category Risk,” Journal of the Academy of Marketing Science, 33 (2), 184-196.

DeMartino, Richard and Robert Barbato (2003), "Differences Between Women and Men MBA Entrepreneurs: Exploring Family Flexibility and Wealth Creation as Career Motivators,” Journal of Business Venturing, 18 (6), 815-832. 
Doney, Patricia M. and Joseph P. Cannon (1997), “An Examination of the Nature of Trust in Buyer-Seller Relationships,” Journal of Marketing, 61 (April), 35-51.

Dowling, Graham R. and Richard Staelin (1994), “A Model of Perceived Risk and Intended Risk-Handling Activity, Journal of Consumer Research, 21 (1), 119-134.

Eastlick, Mary Ann and Richard A. Feinberg (1999), "Shopping Motives of Mail Catalog Shopping,” Journal of Business Research, 45 (3), 281-290.

Eddleston, Kimberly A and Gary N. Powell (2008), "The Role of Gender Identity in Explaining Sex Differences in Business Owners' Career Satisfier Preferences,” Journal of Business Venturing, 23 (2), 244-256.

Fornell, Claes and David F. Larcker (1981), "Evaluating Structural Equation Models with Unobservable Variables and Measurement Error,” Journal of Marketing Research, 18 (February), 39-50.

Gaski, John F. and John R. Nevin (1985), "The Differential Effects of Exercised and Unexercised Power Sources in a Marketing Channel”, Journal of Marketing Research, 22 (2), 130-142.

Gerbing, David W. and James C. Anderson (1988), “An Updated Paradigm for Scale Development Incorporating Uni-dimensionality and its Assessment,” Journal of Marketing Research, 25 (May), 186-192.

Geyskens, Inge, Jan-Benedict E. M. Steenkamp and Nirmalya Kumar (1999) "A MetaAnalysis of Satisfaction in Marketing Channel Relationships," Journal of Marketing Research, 36 (2), 223-238.

Gilligan, Carol (1982), In a Different Voice, Massachusetts, Harvard University Press.

Grace, Debra and Aron O’Cass (2005), “An Examination of Antecendents of Repatronage Intentions Across Different Retail Store Formats," Journal of Retailing and Consumer Services, 12, 227 - 243

Grewal, Dhruv, Kent B. Munroe and R. Krishnan (1998), “The Effects of Price Comparison Advertising on Buyers' Perceptions of Acquisition Value, Transaction Value, and Behavioral Intentions,” Journal of Marketing, 62 (April), 46-59.

Grünhagen, Marko, Robin B. DiPietro, Robert E. Stassen and Lorelle Frazer (2008), “The Effective Delivery of Franchisor Services: A Comparison of U.S. and German Support Practices for Franchisees,” Journal of Marketing Channels, 15 (4), 315-335.

Grünhagen, Marko and Michael J. Dorsch (2003), "Does the Franchisor Provide Value to Franchisees? Past, Current, and Future Value Assessments of Two Franchisee Types,” Journal of Small Business Management, 41 (4), 366-384.

Grünhagen, Marko, Michael J. Dorsch and Melody L. Wollan (2008), "Recall of Autobiographical Memory: A Longitudinal Analysis of Franchisee Experts,” International Entrepreneurship and Management Journal, 4 (1), 19-33.

Gupta, Sunil and Valarie Zeithaml (2006), “Customer Metrics and Their Impact on Financial Performance,” Marketing Science, 25 (6), 718-739.

Hakannson, Hakan (1982), International Marketing and Purchasing of Industrial Goods: An Interaction Model. John Wiley and Sons.

Harmon, Tracy R. and Merlyn A. Griffiths (2008), "Franchisee Perceived Relationship Value,” Journal of Business \& Industrial Marketing, 23 (4), 256-263.

Hennig-Thurau, Thorsten, Kevin P. Gwinner and Dwayne D. Gremler (2002), “An Integration of Relational Benefits and Relationship Quality,” Journal of Service Research, 4 (3), 230-247.

Holbrook, Morris.B (2006), “Consumption Experience, Customer Value, and Subjective Personal Introspection: An Illustrative Photographic Essay,” Journal of Business Research, 59, 714-725 
Holbrook, Morris B. (1994), “The Nature of Customer Value: An Axiology of Services in the Consumption Experience, ‘ in Roland Rust, Richard L. Oliver (Eds.), Service Quality: New Directions in Theory and Practice, Newbury Park, CA: Sage.

Huang, Yu-An and Ian Phau (2009), "Mapping the Profiles of Franchisees," Direct Marketing: An International Journal, 2(4), 221-238.

Huber, Frank, Andreas Herrmann and Robert E. Moran (2001), “Gaining Competitive Advantage Through Customer Value Oriented Management, Journal of Consumer Marketing, 18 (1), 41-53.

Hunt, Shelby D. and John R. Nevin (1974), "Power in a Channel of Distribution: Sources and Consequences”' Journal of Marketing Research, XI (May), 186-193

Jambulingam, Thani and John R. Nevin (1999), "Influence of Franchisee Selection Criteria on Outcomes Desired by the Franchisor,” Journal of Business Venturing, 14 (4), 363-396.

James, Lawrence R., Stanley A. Mulaik and Jeanne M. Brett (2006), “A Tale of Two Methods,” Organizational Research Methods, 9 (2), 233-244.

Johnson, Michael D., Anders Gustafsson, Tor Wallin Andreassen, Line Lervik and Jaesung Cha (2001), "The Evolution and Future of National Customer Satisfaction Index Models,” Journal of Economic Psychology, 22 (2), 217-245.

Kalwani, Manoha U. and Narakesari Narayandas (1995), "Long Term Manufacturing-supplier Relationships: Do They Pay Off For Supplier Firms?” Journal of Marketing, 59 (1), 116.

Kaufmann, Patrick J. (1999), "Franchising and the Choice of Self-Employment,” Journal of Business Venturing, 14 (4), 345-362.

Kaufmann, Patrick J. and Rajiv P. Dant (1998), "Franchising and the Domain of Entrepreneurship Research,” Journal of Business Venturing, 14 , 5-16.

Keil, Mark, Kwok-Kee Wei, Bernard C.Y. Tan, Timo Saarinen, Virpi Tuunainen and Arjen Wassanaar (2000), “A Cross-Cultural Study on Escalation of Commitment Behavior in Software Projects,” MIS Quarterly, 24 (2), 299-325.

Lam, Shun Yin, Venkatesh Shankar and M. Krishna Erramilli Bvsan Murthy (2004), "Customer Value, Satisfaction, Loyalty, and Switching Costs: An Illustration from a Business-to-Business Service Context,” Journal of the Academy of Marketing Science, 32 (3), 293-311.

Leite, Walter L., I-Chan Huang and George A. Marcoulides (2008), "Item Selection for the Development of Short Forms of Scales Using an Ant Colony Optimization Algorithm,” Multivariate Behavioral Research, 43 (3), 411-431.

Li, Zhan G. and Rajiv P. Dant (1997), “ An Exploratory Study of Exclusive Dealing in Channel Relationships,” Journal of the Academy of Marketing Science, 25 (3), 201213.

Lin, Chien-Hsin, Peter J. Sher and Hsin-Yu Shih (2005), "Past Progress and Future Directions in Conceptualizing Customer Perceived Value,” Journal of Service Industry Management, 16 (3/4), 318-336.

Lindell, Michael K. and David J. Whitney (2001), “Accounting for Common Method Variance in Cross-Sectional Research Designs,” Journal of Applied Psychology, 86 (1), 114-121.

Luo, Zueming and C.B. Bhattacharya (2006), "Corporate Social Responsibility, Customer Satisfaction, and Market Value,” Journal of Marketing, 70 (October), 1-18.

MacCrimmon, Kenneth R. and Donald A. Wehrung (1986), Taking Risks: The Management of Uncertainty, New York, The Free Press.

MacKay, Hugh (1999), Turning Point: Australians Choosing Their Future, Sydney: MacMillan. 
Mason, Roger (2005), "Missing Links: Product Classification Theory and the Social Characteristics of Goods," Marketing Theory, 5 (3), 309-322.

Mason, Roger (1984), “Conspicuous Consumption: A Literature Review,” European Journal of Marketing, 18 (3), 26-39.

McKay, Ruth (2001), "Women Entrepreneurs: Moving Beyond Family and Flexibility," International Journal of Entrepreneurial Behavior and Research, 7 (4), 148-165.

Merz, Michael A., Yi He and Stephen L. Vargo (2009), "The Evolving Brand Logic: A Service-Dominant Logic Perspective,” Journal of the Academy of Marketing Science, 37, 328-344.

Moliner, Miguel A., Javier Sánchez, Rosa M. Rodríguez and Luis Callarisa (2005), "Perceived Relationship Quality and Post-Purchase Perceived Value,” European Journal of Marketing, 41 (11/12), 1392-1422.

Michael, Steven C. (1999), “Do Franchised Chains Advertise Enough?” Journal of Retailing, 75 (4), 461-478.

Michael, Steven. C. (1996). “To Franchise or Not to Franchise: An Analysis of Decision Rights and Organizational Form Shares,” Journal of Business Venturing, 11 (January), 57-71.

Michael, Steven C. and James G. Combs (2008) "Entrepreneurial Failure: The Case of Franchisees,” Journal of Small Business Management, 46 (1), 73-90.

Miniard, Paul W. and Joel B. Cohen (1983), "Modeling Personal and Normative Influences on Behavior," Journal of Consumer Research, 10 (2), 169-180.

Mitchell, Vincent-Wayne (1999), "Consumer Perceived Risk: Conceptualisations and Models,” European Journal of Marketing, 33 (1/2), 163-195.

Morgan, Robert M. and Shelby D. Hunt (1994), "The Commitment-Trust Theory of Relationship Marketing,” Journal of Marketing, 58 (3), 20-38.

Morrison, Kimberley A. (1997), "How Franchise Job Satisfaction and Personality Affects Performance, Organizational Commitment, Franchisor Relations, and Intention to Remain,” Journal of Small Business Management, 35 (3), 39-66.

Olsen, Shirley F. and Helen M. Currie (1992), "Female Entrepreneurs: Personal Value Systems, and Business Strategies in a Male Dominated Industry,” Journal of Small Business Management, 30 (1), 49-58.

Palmatier, Robert W. (2008), “Interfirm Relational Drivers of Customer Value,” Journal of Marketing, 72 (July), 76-89.

Parasuraman, A. (1997), "Reflections on Gaining Competitive Advantage Through Customer Value,” Journal of the Academy of Marketing Science, 25 (2), 154-161.

Parasuraman, A., Valarie L. Zeithaml and Leonard L. Berry (1985), “A Conceptual Model of Service Quality,” Journal of Marketing, 49 (Fall), 41-50.

Payne, Adrian F., Kaj Storbacka and Pennie Frow (2008), "Managing the Co-creation of Value,” Journal of the Academy of Marketing Science, 36 (1), 83-96.

Peterson, Alden and Rajiv P. Dant (1990). "Perceived Advantages of the Franchise Option from the Franchisee Perspective: Empirical Insights from a service Franchise,' Journal of Small Business Management, 28 (3), pp. 46-61.

Podsakoff, Philip M., Scott B. MacKenzie, Jeong-Yeon Lee and Nathan P. Podsakoff (2003), "Common Method Biases in Behavioral Research: A Critical Review of the Literature and Recommended Remedies,” Journal of Applied Psychology, 88 (5), 879-903.

Porter, James, L. and William. Renforth (1978), "Franchise Agreements: Spotting the Important Legal Issues,” Journal of Small Business Management, 16 (4), 27-31.

Ravald, Annika and Christian Gronroos (1996), “The Value Concept and Relationship Marketing,” European Journal of Marketing, 30 (2), 19-30. 
Roh, Eugene Y. and Ji-Hwan Yoon (2009), “Franchisor’s Ongoing Support and franchisee’s Satisfaction: A Case of Ice Cream Franchising in Korea,” International Journal of Contemporary Hospitality Management, 21 (1), 85-99.

Scheer, Lisa. K and Louis W. Stern (1992) "The Effect of Influence Type and Performance Outcomes on Attitude Toward the Influencer. Journal of Marketing Research, 29 (1), 128-142.

Schul, Patrick L., Taylor E. Little and William M. Pride (1985), “Channel Climate: Its Impact on Channel Member Satisfaction, Journal of Retailing, 61, 9-38.

Scott, Frank. A. Jr. (1995). "Franchising vs. Company Ownership as a Decision Variable of the Firm," Review of Industrial Organization, 10 (1) , 69-81.

Sheth, Jagdish, Bruce I, Newmann and Barbara L. Gross (1991), Consumption Values and Market Choices: Theory and Applications, Cincinnati, OH: Southwest Publishing.

Sitkin, Sim B. and Amy L. Pablo (1992), "Reconceptualising the Determinants of Risk Behavior,” Academy of Management Review, 17 (1), 9-38.

Smith, Brock J., and Mark Colgate (2007), "Customer Value Creation: A Practical Framework," Journal of Marketing Theory and Practice, 15(1), 7-23.

Sorenson, Ritch L., Calthleen A. Folker and Keith H. Brigham (2008), "The Collaborative Network Orientation: Achieving Business Success through Collaborative Relationships," Entrepreneurship Theory and Practice, 32 (4), 615-634.

Spiteri, Joseph M. and Paul A. Dion (2004), "Customer Value, Overall Satisfaction, End-User Loyalty, and Market Performance in Detail Intensive Industries," Industrial Marketing Management, 33 (8), 675-687.

Sweeney, Jillian C. and Geoffrey N. Soutar (2001), "Consumer Perceived Value: The Development of a Multiple Item Scale,” Journal of Retailing, 77, 203-220.

Sweeney, Jillian C, Geoff Soutar and Lester Johnson (1999), "The Role of Perceived Risk in the Quality-Value Relationship: A Study in a Retail Environment,” Journal of Retailing, 75 (1), 77-105.

Sweeney, Jillian C. and David A. Webb (2000), "Relationship Benefits: An Exploration of Buyer-Supplier Dyads,” Journal of Relationship Marketing, 1 (2), 77-92.

Tikoo, Surinder (2002), "Franchiser Influence Strategy Use and the Franchisee Experience and Dependence,” Journal of Retailing, 78 (3), 183-192.

Tomzack, Mary E (1994), Tips and Traps When Buying a Franchise, New York, N. Y., McGraw Hill.

Ulaga, Wolfgang and Andreas Eggert (2006), "Relationship Value in Business Markets: The Construct and Its Dimensions,” Journal of Business-to-Business Marketing, 12 (1), 73-99.

Vargo, Stephen L. and Robert F. Lusch (2006), "Service-Dominant Logic: What It Is, What It Is Not, What It Might Be,” In The Service-Dominant Logic of Marketing: Dialog, D Debate and Directions, R.F. Lusch and S.L. Vargo (Eds.), pp. 43-56. Armonk: M.E. Sharpe Inc.

Vargo, Stephen L. and Robert F. Lusch (2004), "Evolving to a New Dominant Logic for Marketing,” Journal of Marketing, 68, 1-16.

Vargo, Stephen L., Paul P. Maglio and Melissa Archpru Akaka (2008), “On Value and Value Co-Creation: A Service Systems and Service Logic Perspective,” European Management Journal, 26, 145-152.

Veblen, Thorstein (1912) The Theory of the Leisure Class: An Economic Study of Institutions. London, George Allen and Unwin.

Weaven, Scott, Jennifer Isaac and Carmel Herington (2008), "Franchising as a Path to SelfEmployment for Australian Female Entrepreneurs," Journal of Management and Organization, 13, 345-365. 
Weaven, Scott K., Debra A. Grace and Mark Manning (2009), "Franchisee Personality: An Examination in the Context of Franchise Unit Density and Service Classification," European Journal of Marketing, 43 (1/2), 90-109.

Whittaker, Graham, Lesley Ledden, Stavros P. Kalafatis. (2007), “A Re-Examination of the Relationship Between Value, Satisfaction and Intention in Business Services. Journal of Services Marketing 21:5, 345-357

Wong, C-S, and Kenneth S. Law (2002), "The Effects of Leader and Follower Emotional Intelligence on Performance and Attitude: An Exploratory Study,” The Leadership Quarterly, 13 (3), 243-274.

Woodruff, Robert B (1997), "Customer Value: The Next Source for Competitive Advantage,” (Eds), Journal of the Academy of Marketing Science, 25 (2), 139-53.

Woodruff, Robert B., and Daniel J. Flint (2006), "Marketing's Service-Dominant Logic and Customer Value,” In Robert F. Lusch and Stephen L. Vargo (Eds.) In The ServiceDominant Logic of Marketing: Dialog, D Debate and Directions, R.F. Lusch and S.L. Vargo (Eds.), pp. 43-56. Armonk: M.E. Sharpe Inc.

Yang, Zhilin and Robin T. Peterson (2004), "Customer Perceived Value, Satisfaction and Loyalty: The Role of Switching Costs,” Psychology and Marketing, 21 (10), 799-822.

Yu, Hueiju and Wenchang Fang (2009), "Relative Impacts from Product Quality, Service Quality, and Experience Quality on Customer Perceived Value and Intention to Shop for the Coffee Shop Market,” Total Quality Management and Business Excellence, 20 (11), 1273-1285.

Zeithaml, Valarie A. (1988). "Consumer Perceptions of Price, Quality, and Value: A MeansEnd Model and Synthesis of Evidence,” Journal of Marketing, 52 (July), 2-12. 
Table 1. Results of the Measurement Model

\begin{tabular}{|c|c|c|c|c|}
\hline Construct & Item & SL & CR & AVE \\
\hline \multirow{4}{*}{$\begin{array}{l}\text { SOCI AL VALUE } \\
\text { (Construct } \\
\text { deleted from } \\
\text { final analysis) }\end{array}$} & Owning this franchise helps me feel accepted - DELETED & - & \multirow[t]{4}{*}{.97} & \multirow[t]{4}{*}{.92} \\
\hline & Owning this franchise improves the way I am perceived & .93 & & \\
\hline & Owning this franchise makes a good impression on others & .94 & & \\
\hline & Owning this franchise gives me social approval & .82 & & \\
\hline \multirow{4}{*}{$\begin{array}{l}\text { EMOTI ONAL } \\
\text { VALUE } \\
\text { (EMOVAL) }\end{array}$} & I enjoy owning this franchise & .92 & \multirow[t]{4}{*}{.99} & \multirow[t]{4}{*}{.95} \\
\hline & I feel relaxed about owning this franchise & .90 & & \\
\hline & I am pleased I own this franchise & .97 & & \\
\hline & Owning this franchise makes me feel good & .94 & & \\
\hline \multirow{4}{*}{$\begin{array}{l}\text { QUALI TY VALUE } \\
\text { (QUALVAL) }\end{array}$} & My franchise performs consistently & .79 & \multirow[t]{4}{*}{.96} & \multirow[t]{4}{*}{.91} \\
\hline & My franchise will be around for a long time & .90 & & \\
\hline & My franchise is a quality business & .91 & & \\
\hline & I operate within a high quality franchise system - DELETED & - & & \\
\hline \multirow{4}{*}{$\begin{array}{l}\text { MONETARY } \\
\text { VALUE } \\
\text { (MONVAL) }\end{array}$} & My franchise was reasonably priced & .88 & \multirow[t]{4}{*}{.93} & \multirow[t]{4}{*}{.83} \\
\hline & My franchise arrangement offers value for money & .87 & & \\
\hline & Buying this franchise has provided economical value & .96 & & \\
\hline & My franchise was a good purchase for the price - DELETED & - & & \\
\hline \multirow{4}{*}{$\begin{array}{l}\text { I NVESTMENT } \\
\text { RISK } \\
\text { (RISK) }\end{array}$} & $\begin{array}{l}\text { Considering the potential investment involvement, entering } \\
\text { into a franchising arrangement is very risky. }\end{array}$ & .70 & \multirow[t]{4}{*}{.91} & \multirow[t]{4}{*}{.73} \\
\hline & $\begin{array}{l}\text { Given the price involved in buying a franchise, there is } \\
\text { substantial monetary risk associated with this purchase. }\end{array}$ & .72 & & \\
\hline & Buying a franchise is a bad way of spending money & .75 & & \\
\hline & Buying a franchise is a good investment (R) & .79 & & \\
\hline \multirow{3}{*}{$\begin{array}{l}\text { RELATI ONSHI P } \\
\text { SATI SFACTI ON } \\
\text { (SATIS) }\end{array}$} & My relationship with my franchisor has been productive & .98 & \multirow[t]{3}{*}{.98} & \multirow[t]{3}{*}{.97} \\
\hline & The relationship with my franchisor has been satisfactory & .99 & & \\
\hline & $\begin{array}{l}\text { The time and effort I have spent in the relationship with } \\
\text { my franchisor has been worthwhile }\end{array}$ & .96 & & \\
\hline
\end{tabular}

$\mathrm{SL}=$ Standardized Loadings; $\mathrm{CR}=$ Composite Reliability; AVE = Average Variance Extracted 
Table 2: Results of Discriminant Analysis

\begin{tabular}{|c|c|c|c|c|c|c|c|c|}
\hline \multicolumn{2}{|c|}{ Comparisons } & \multicolumn{2}{|c|}{$\begin{array}{c}\text { Constrained } \\
\text { Model }\end{array}$} & \multicolumn{2}{|c|}{$\begin{array}{c}\text { Unconstrained } \\
\text { Model }\end{array}$} & \multicolumn{2}{|c|}{$\begin{array}{l}\text { Chi-Square } \\
\text { Difference }\end{array}$} & \multirow[t]{2}{*}{$\begin{array}{c}\text { Discriminant } \\
\text { Validity }\end{array}$} \\
\hline & & $x^{2}$ & df & $x^{2}$ & $\mathrm{df}$ & $\Delta X^{2}$ & $\Delta \mathrm{df}$ & \\
\hline \multirow[t]{5}{*}{ SOCVAL } & SATIS & 8.14 & 9 & 5.51 & 8 & 2.63 & 1 & No \\
\hline & RISK & 152.71 & 13 & 11.41 & 13 & 141.30 & 1 & Yes \\
\hline & EMOVAL & 44.61 & 14 & 40.81 & 13 & 3.80 & 1 & No \\
\hline & QUALVAL & 9.00 & 14 & 9.02 & 13 & 0.02 & 1 & No \\
\hline & MONVAL & 6.70 & 14 & 5.19 & 13 & 1.51 & 1 & No \\
\hline \multirow[t]{4}{*}{ EMOVAL } & SATIS & 138.33 & 14 & 39.13 & 13 & 99.20 & 1 & Yes \\
\hline & RISK & 338.46 & 20 & 55.73 & 19 & 282.73 & 1 & Yes \\
\hline & QUALVAL & 59.31 & 14 & 34.57 & 13 & 24.74 & 1 & Yes \\
\hline & MONVAL & 104.35 & 14 & 78.47 & 13 & 25.88 & 1 & Yes \\
\hline \multirow[t]{3}{*}{ QUALVAL } & SATIS & 55.39 & 9 & 23.43 & 8 & 31.96 & 1 & Yes \\
\hline & RISK & 283.21 & 14 & 8.78 & 13 & 274.43 & 1 & Yes \\
\hline & MONVAL & 62.37 & 9 & 49.81 & 8 & 12.56 & 1 & Yes \\
\hline \multirow[t]{2}{*}{ MONVAL } & SATIS & 91.32 & 9 & 43.59 & 8 & 47.73 & 1 & Yes \\
\hline & RISK & 279.19 & 14 & 18.94 & 13 & 260.25 & 1 & Yes \\
\hline SATIS & RISK & 354.10 & 14 & 142.23 & 13 & 211.87 & 1 & Yes \\
\hline
\end{tabular}


Table 3: Structural Model Results - Overall Model

\begin{tabular}{|c|c|c|c|c|c|}
\hline $\begin{array}{l}\text { Dependent } \\
\text { Variables }\end{array}$ & $\begin{array}{l}\text { I ndependent } \\
\text { Variables }\end{array}$ & Hypotheses & $\begin{array}{c}\text { Beta } \\
\text { Weight }\end{array}$ & $\begin{array}{c}\text { Critical } \\
\text { Ratio }\end{array}$ & $\mathbf{R}^{2}$ \\
\hline Relationship & & & & & .79 \\
\hline \multirow{4}{*}{ Satisfaction } & Investment Risk & $\mathrm{H} 1$ & -.29 & -3.70 & Sig \\
\hline & Emotional Value & $\mathrm{H} 3 \mathrm{~b}$ & .54 & 8.61 & Sig \\
\hline & Quality Value & $\mathrm{H} 4 \mathrm{~b}$ & .04 & 0.65 & $\mathrm{~N} / \mathrm{S}$ \\
\hline & Monetary Value & $\mathrm{H} 5 \mathrm{~b}$ & .18 & 3.16 & Sig \\
\hline \multirow[t]{4}{*}{ Investment Risk } & & & & & .65 \\
\hline & Emotional Value & $\mathrm{H} 3 \mathrm{a}$ & -.31 & -3.31 & Sig. \\
\hline & Quality Value & $\mathrm{H} 4 \mathrm{a}$ & -.30 & -2.96 & Sig. \\
\hline & Monetary Value & $\mathrm{H} 5 \mathrm{a}$ & -.26 & -3.03 & Sig. \\
\hline
\end{tabular}

Fit of Model: $X^{2}=182.31(\mathrm{df}=108, \mathrm{p}<.05)$, GFI .93, CFI .99, TLI .98 and RMSEA .05 .

Two-tailed significance testing i.e. $p<.01$ 
Table 4: Mediation Analysis Results

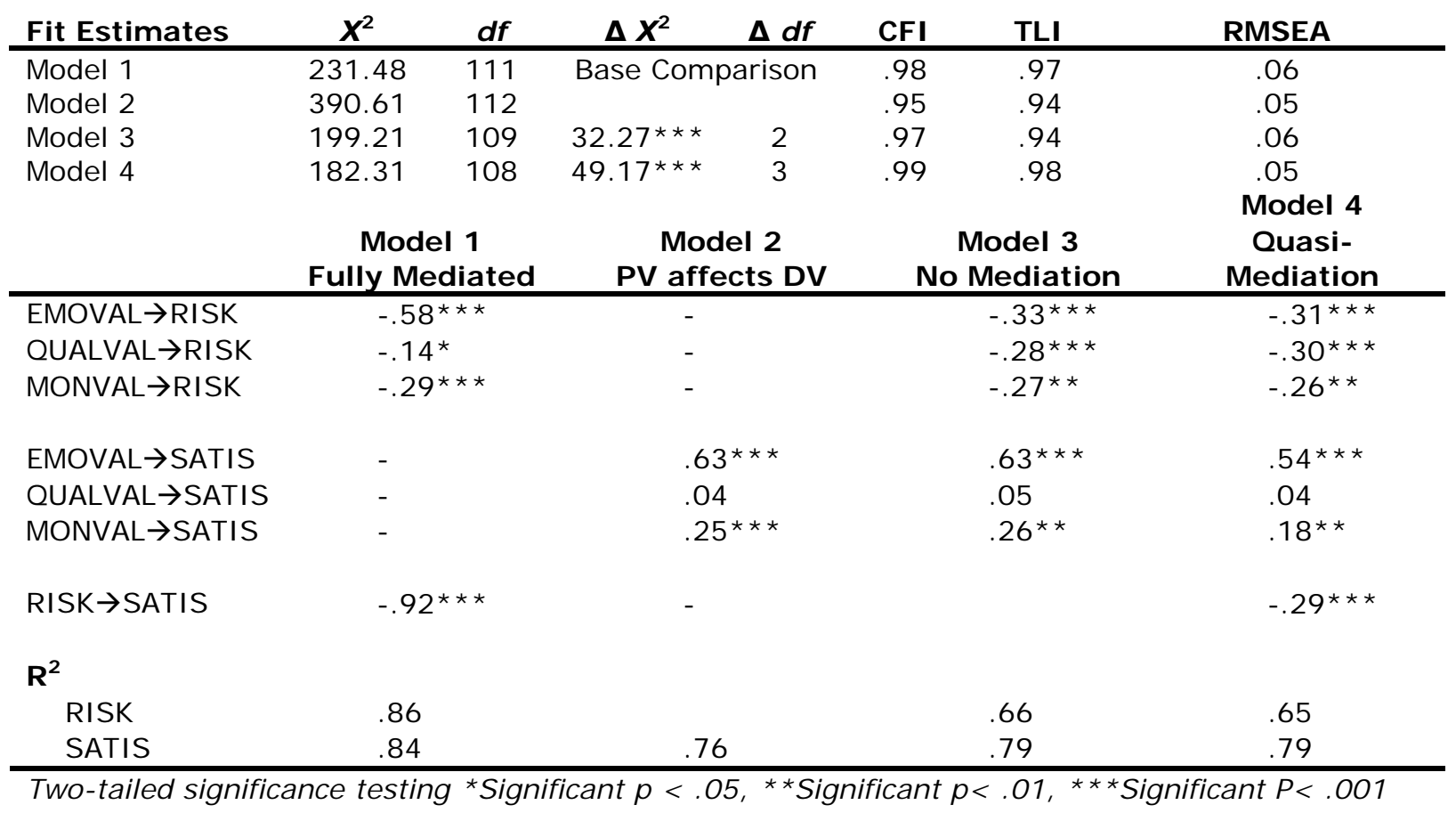


Table 5: Comparing Models - Male versus Female

\begin{tabular}{|c|c|c|c|c|c|}
\hline $\begin{array}{l}\text { Predicted } \\
\text { Variables }\end{array}$ & $\begin{array}{l}\text { Predictor } \\
\text { Variables }\end{array}$ & Beta & Critical Ratio & $\mathbf{R}^{2}$ & Model Fit \\
\hline \multicolumn{6}{|c|}{ MODEL A: MALES $(\mathbf{N}=183)$} \\
\hline $\begin{array}{l}\text { Relationship } \\
\text { Satisfaction }\end{array}$ & $\begin{array}{l}\text { Investment Risk } \\
\text { Emotional Value } \\
\text { Quality Value } \\
\text { Monetary Value }\end{array}$ & $\begin{array}{l}-.38 \\
.43 \\
.02 \\
.17\end{array}$ & $\begin{array}{r}-3.30 \\
5.13 \\
* 0.19 \\
2.38\end{array}$ & .80 & $\begin{array}{l}X^{2}=156.12 \\
\mathrm{df}=108\end{array}$ \\
\hline $\begin{array}{l}\text { Investment } \\
\text { Risk }\end{array}$ & $\begin{array}{l}\text { Emotional Value } \\
\text { Quality Value } \\
\text { Monetary Value }\end{array}$ & $\begin{array}{l}-.35 \\
-.33 \\
-.23\end{array}$ & $\begin{array}{l}-2.77 \\
-2.40 \\
-2.16\end{array}$ & .70 & $\begin{array}{l}\mathrm{GFI}=.91 \\
\mathrm{TLI}=.97 \\
\mathrm{CFI}=.98 \\
\mathrm{RMSEA}=.05\end{array}$ \\
\hline \multicolumn{6}{|c|}{ MODEL B: FEMALES $(\mathbf{N}=\mathbf{8 0})$} \\
\hline $\begin{array}{l}\text { Relationship } \\
\text { Satisfaction }\end{array}$ & $\begin{array}{l}\text { Investment Risk } \\
\text { Emotional Value } \\
\text { Quality Value } \\
\text { Monetary Value }\end{array}$ & $\begin{array}{l}-.17 \\
.43 \\
.03 \\
.42\end{array}$ & $\begin{array}{r}*-1.35 \\
3.32 \\
* 0.29 \\
3.20\end{array}$ & .81 & $\begin{array}{l}X^{2}=166.08 \\
\mathrm{df}=108\end{array}$ \\
\hline $\begin{array}{l}\text { Investment } \\
\text { Risk }\end{array}$ & $\begin{array}{l}\text { Emotional Value } \\
\text { Quality Value } \\
\text { Monetary Value }\end{array}$ & $\begin{array}{l}-.02 \\
-.43 \\
-.42\end{array}$ & $\begin{array}{r}*-0.97 \\
-2.14 \\
3.20\end{array}$ & .64 & $\begin{array}{l}\mathrm{GFI}=.78 \\
\mathrm{TLI}=.95 \\
\mathrm{CFI}=.97 \\
\mathrm{RMSEA}=.09\end{array}$ \\
\hline
\end{tabular}

Two-tailed significance testing * Not Significant 
Figure 1: Hypothesized Model

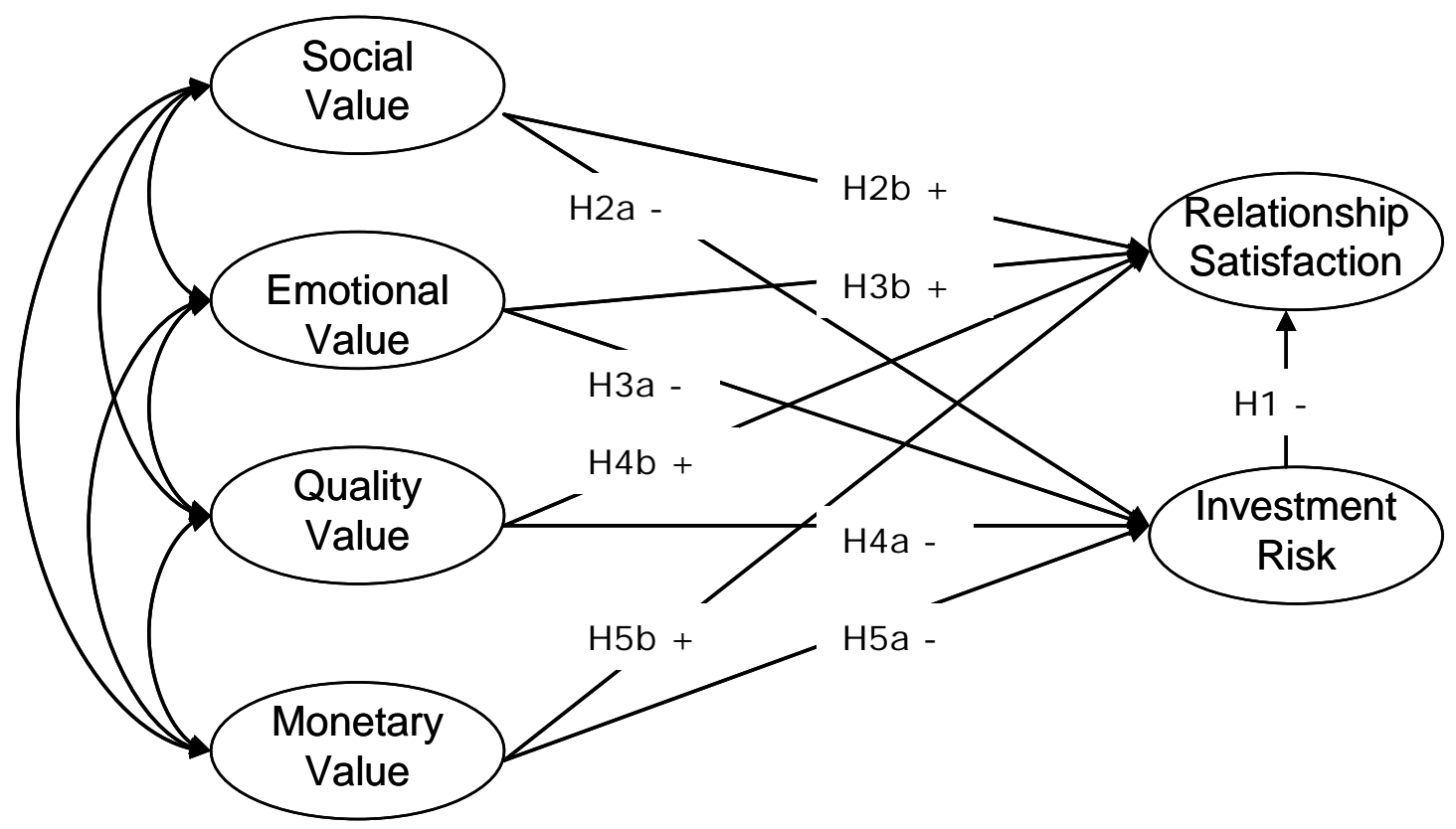


Figure 2: Results: Final Analysis Model

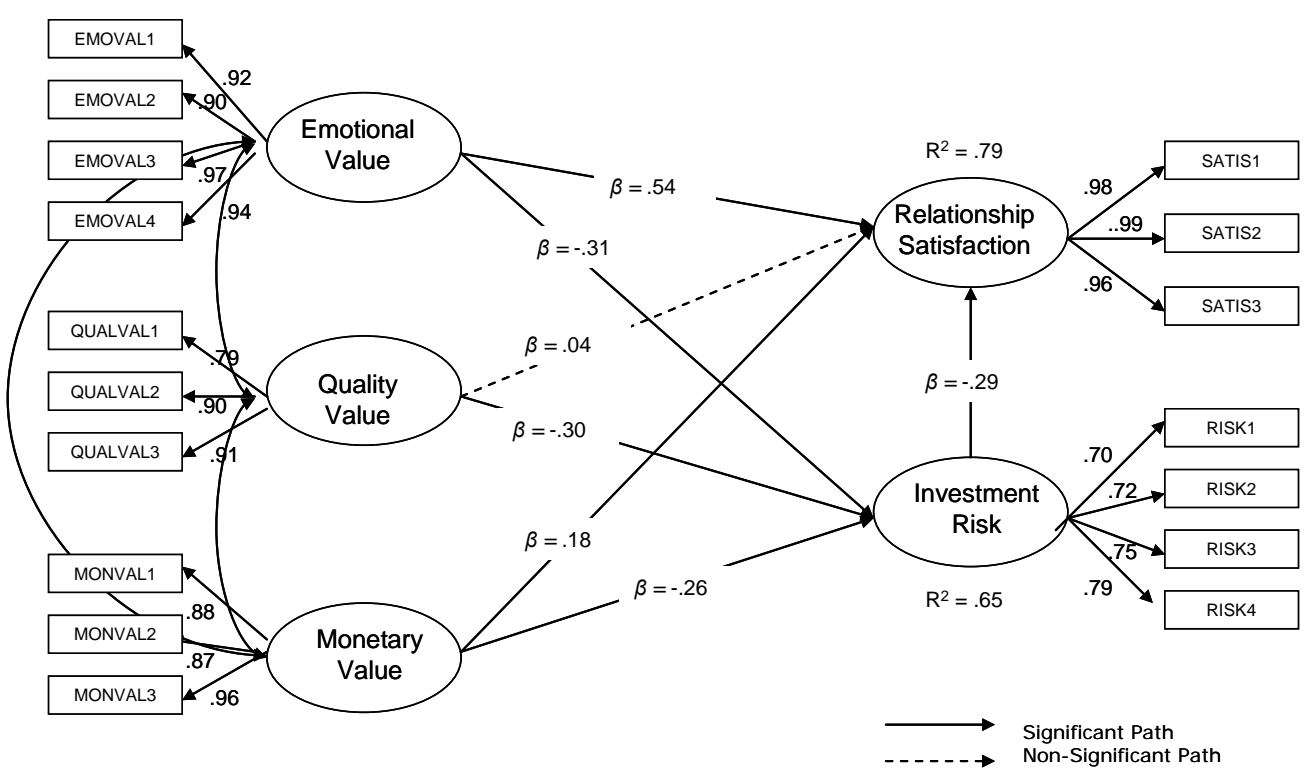

All Standardized Loadings Significant

Fit of Model: $X^{2}=182.31(\mathrm{df}=108, p<.05)$, GFI .93, CFI .99, TLI .98 and RMSEA .05. 
Figure 3: Gender Results

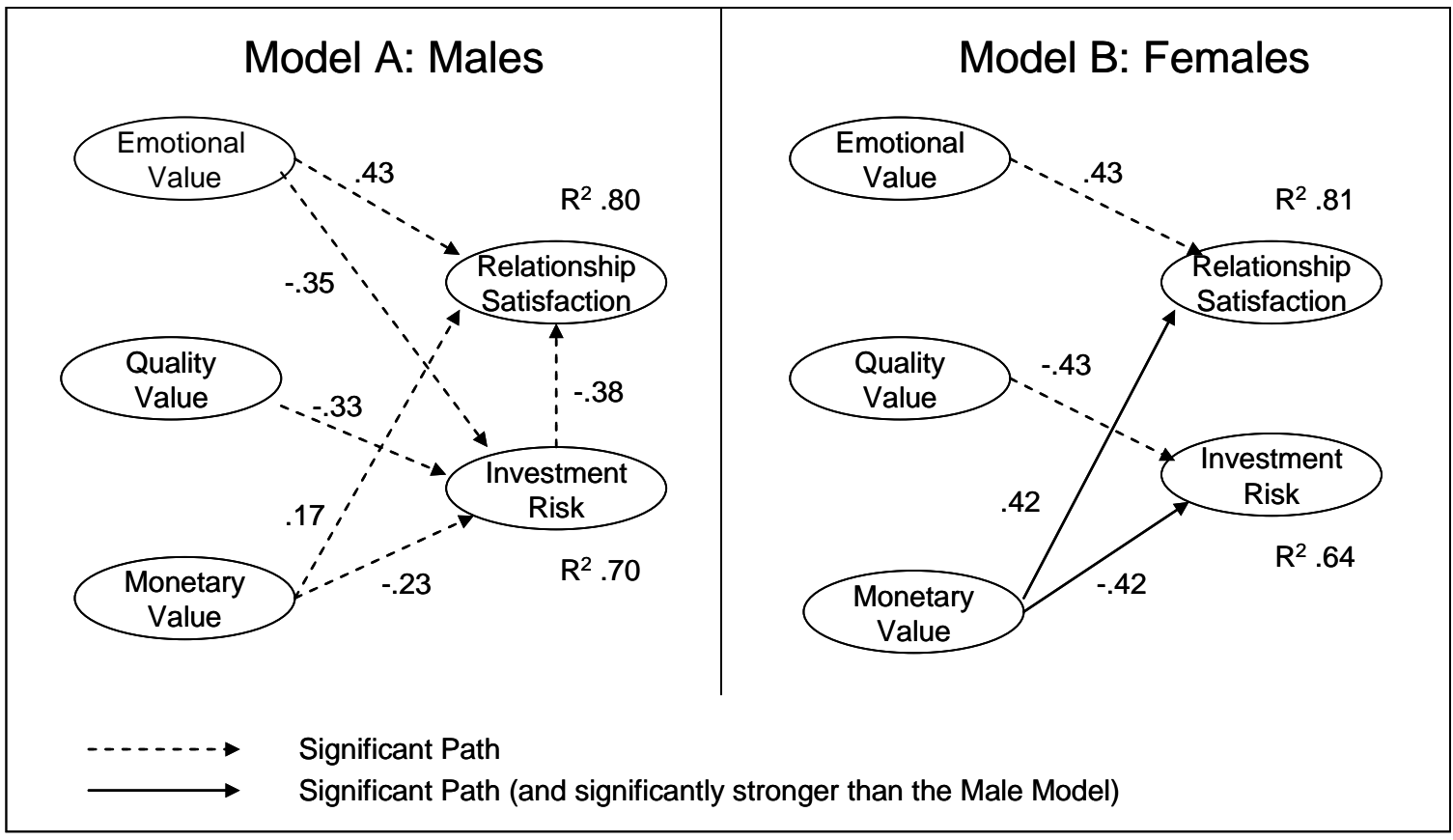

